\section{NK30424A and B, Novel Inhibitors of Lipopolysaccharide-induced Tumour Necrosis Factor Alpha Production, Produced by Streptomyces sp. NA30424}

Sir:

Human tumour necrosis factor alpha (TNF- $\alpha$ ) promoter contains motifs that resemble NF- $\kappa \mathrm{B}$-binding sites. It has been suggested that NF- $\kappa \mathrm{B}$ is an important factor in lipopolysaccharide (LPS)-induced TNF- $\alpha$ production ${ }^{1)}$. $\mathrm{NF}-\kappa \mathrm{B}$ normally resides in cytoplasm as an inactivated form by forming a complex with I $\kappa \mathrm{B}-\alpha$. Upon LPS stimulation, $\mathrm{I} \kappa \mathrm{B}-\alpha$ is rapidly phosphorylated by $\mathrm{I} \kappa \mathrm{B}$ kinase 2 (IKK2) and degraded, allowing NF- $\kappa \mathrm{B}$ to translocate to the nucleus, where it participates in transcriptional regulation of target genes such as TNF- $\alpha^{2)}$. NF- $\kappa \mathrm{B}$ signaling pathway is thought to be the target for antiinflammatory agents because it activates various gene expression involved in inflammation. In addition, increasing evidence supports its role in regulating cell growth, oncogenesis and protection from cell death ${ }^{3)}$.

We screened inhibitors of LPS-induced TNF- $\alpha$ production with a reporter assay system and found NK30424A and B which have ability to suppress LPSinduced TNF- $\alpha$ production below $1 \mu \mathrm{M}$, from the fermentation broth of Streptomyces sp. NA30424. NK30424A was a unique glutarimide compound having an unsaturated 12-membered lactone containing cysteine moiety, and NK30424B was a stereoisomer of A (Fig. 1). We expect that NK30424A and B inhibit LPS-induced TNF- $\alpha$ production by suppression of NF- $\kappa \mathrm{B}$ signaling pathway, and have potential for treatment of this pathwaymediated pathophysiological diseases. In this communication, we report our screening strategy, taxonomy of the strain NA30424, production, structure and biological activities of NK $30424 A$ and $B$.

Human TNF- $\alpha$ promoter $(-1021$ to +91 from the transcription initiation site), was amplified with PCR, which was performed using a sense primer ( $5^{\prime}$-GGAAAAGTCAGGGTCTGGAG-3') and an antisense primer (5'-ATGTGGCGTCTGAGGGTTGT-3'). $\quad \beta$-Galactosidase (lac $Z$ ) reporter gene expression vector pGV-Gal was constructed from pGL2 (Promega) in our laboratory. To construct the reporter plasmid, TNF- $\alpha$ promoter DNA and the neomycin resistance gene were inserted into pGV-Gal. After this plasmid was transfected into the murine macrophage cell line J774.1 (ATCC culture collection), stable transfectants, which showed LPS (E. coli $026: \mathrm{B} 6$, DIFCO)-induced $\beta$-galactosidase production, were selected in the presence of $0.05 \mathrm{mg} / \mathrm{ml}$ of G418 in RPMI- 1640 medium with 5\% fetal bovine serum (lot No. 13233, Uniglobe Research Corporation). Inhibitors of TNF- $\alpha$ promoter activity were screened with this stable transfectants as described below. After cells $\left(2 \times 10^{4}\right.$ cells/well) were plated in 96 well microplates dish and were cultured for 16 hours, each of test sample was added to cells, followed immediately by addition of LPS $(1 \mu \mathrm{g} / \mathrm{ml})$. Cells incubated without LPS served as controls for the baseline activity of TNF- $\alpha$ promoter. Cultures incubated with LPS in the absence of test samples served as positive controls for activation of TNF- $\alpha$ promoter activity. Six hours after the addition of LPS, culture medium was removed, and the cells were lysed with freezing and thawing. $\beta$-Galactosidase activity was then measured using 4-methylumbellyferyl-D- $\beta$-garactopyranoside (Wako Pure Chemical Industries) as a substrate. Enzyme reaction was performed in $180 \mu \mathrm{l}$ of reaction buffer $(100 \mathrm{~mm}$ sodium

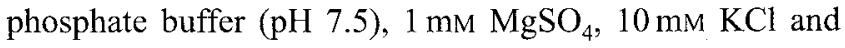
$0.5 \mathrm{mM}$ 4-methylumbellyferyl-D- $\beta$-galactopyranoside) for one hour at room temperature. After the reaction was stopped with $75 \mu \mathrm{l}$ of $300 \mathrm{~mm}$ sodium glycine buffer contained $15 \mathrm{~mm}$ EDTA, fluorescent intensity was measured using fluorescent spectrometer FCA (Baxter) at excitation wavelength $365 \mathrm{~nm}$ and at emission wavelength $450 \mathrm{~nm}$. Among culture extract samples which inhibited LPS-induced $\beta$-galactosidase production in J774.1 stable transfectants, the sample of Streptomyces sp. NA30424 was found and active substances was isolated by its bioactivity.

Strain NA30424 was isolated from soil collected in Kita$\mathrm{ku}$, Tokyo, and has been deposited in the culture collection at the National Institute of Advanced Industrial Science and Technology, Tsukuba, Japan, as Streptomyces sp. NA30424 with an accession number of FERM P-16422. Morphological and physiological properties of the strain were examined according to ShirLing and GotTlieb; several other tests were also performed. Strain NA30424 had branched substrate mycelia, from which aerial hyphae developed in the form of open spirals. No whirl-formation was observed. Matured spore-chains usually bore more 
Fig. 1. The structure of NK30424A (NK30424B is a stereoisomer of NK30424A).

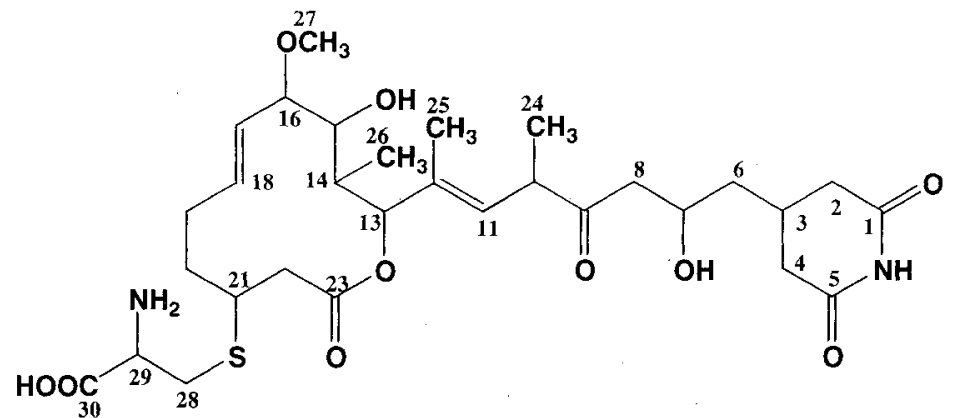

than 10 conical spores. Spores ranged about $0.5-0.9$ by $0.9-$ $1.3 \mu \mathrm{m}$ in size and had a smooth surface. Aerial mass color of the colony was white to brownish gray and gradually glistening with dark gray. The color of vegetative growth was colorless to yellowish brown. Melanoid pigments and the starch hydrolysis were positive, and the proteindecomposing action was negative. The whole-cell hydrolysate of the strain showed that it contained LLdiaminopimelic acid. Based on its characteristics, strain NA30424 was considered to belong to the genus Streptomyces.

A slant culture of the strain NA30424 was inoculated into $100 \mathrm{ml}$ of the seed medium $(2.0 \%$ glycerol, $1.0 \%$ glucose, $0.5 \%$ soybean meal (Ajinomoto Co., Inc.), 0.5\% peptone, $0.5 \%$ yeast extract, $0.05 \% \quad \mathrm{~K}_{2} \mathrm{HPO}_{4}, \quad 0.05 \%$ $\mathrm{MgSO}_{4} \cdot 7 \mathrm{H}_{2} \mathrm{O}$ and $0.2 \% \mathrm{CaCO}_{3}$ ) in a $500-\mathrm{ml}$ Erlenmeyer flask, and cultured on a rotary shaker $(200 \mathrm{rpm})$ for 2 days at $27^{\circ} \mathrm{C}$. One $\mathrm{ml}$ of this seed culture was inoculated into $100 \mathrm{ml}$ of the production medium $(1.0 \%$ glucose, $4.0 \%$ soluble starch, $2.0 \%$ soybean meal, $0.5 \%$ corn steep liquor, $0.03 \% \mathrm{KCl}, 0.05 \% \quad \mathrm{~K}_{2} \mathrm{HPO}_{4}, 0.05 \% \quad \mathrm{MgSO}_{4} \cdot 7 \mathrm{H}_{2} \mathrm{O}$ and $\left.0.2 \% \mathrm{CaCO}_{3}\right)(\mathrm{pH} 6.8)$ in a $500-\mathrm{ml}$ Erlenmeyer flask, and was cultured for 4 days at $27^{\circ} \mathrm{C}$ on a rotary shaker $(200$ rpm).

The culture broth was filtered through Celite and the culture filtrate (14.2 liters) was adsorbed on a Diaion HP-20 column $(5.7 \times 45 \mathrm{~cm})$, which was washed with water and eluted with $80 \%$ aq. $\mathrm{MeOH}$ to give active fraction. The active eluate was concentrated in vacuo to an aqueous solution and extracted with an equal volume of ethyl acetate. An aqueous layer was subjected to a DEAESephadex A 25 column $(4.1 \times 19 \mathrm{~cm})$ chromatography and developed with $50 \mathrm{~mm} \mathrm{NaCl}$ in $50 \mathrm{~mm}$ sodium phosphate buffer $(\mathrm{pH} \mathrm{7.0)}$. The active fractions were combined and adsorbed on a Diaion HP-20ss column $(3 \times 11.5 \mathrm{~cm})$. After washing the column with water, the active substances were eluted with $80 \%$ aq. $\mathrm{MeOH}$. The eluate was concentrated and lyophilized to give an orange powder containing NK30424A and B. The crude powder was further purified by a reverse-phase HPLC using a Capcell Pak $\mathrm{C}_{18}$ column $(2 \times 25 \mathrm{~cm}$, flow rate $7.5 \mathrm{ml} /$ minute, using Shimadzu LC-6A system) with $19 \%$ aq. $\mathrm{CH}_{3} \mathrm{CN}$. The first active fraction contained NK30424A and the second comprised NK30424B. They were collected and lyophilized to afford $150 \mathrm{mg}$ of NK30424A and $490 \mathrm{mg}$ of NK30424B.

Physico-chemical properties of NK30424A and B are summarized in Table 1. The molecular formulae of both compounds were determined to be $\mathrm{C}_{30} \mathrm{H}_{46} \mathrm{~N}_{2} \mathrm{O}_{10} \mathrm{~S}$ on the basis of HRFAB-MS measurement. The results of an X-ray micro analyzer supported the fact that both compounds contained sulfur. They showed the similar UV and IR (KBr) absorption pattern. Optical rotation, the values of $[\alpha]_{\mathrm{D}}(c$ $0.5,20^{\circ} \mathrm{C}$ ) of $\mathrm{NK} 30424 \mathrm{~A}$ and $\mathrm{B}$ were +10.8 and +11.2 , respectively. The ${ }^{13} \mathrm{C}$ NMR spectrum $\left(\mathrm{D}_{2} \mathrm{O}\right)$ of each compound showed 30 resolved peaks (Table 2 ). All ' $\mathrm{H}$ and ${ }^{13} \mathrm{C}$ NMR signals of NK30424A and B were assigned based on analyses of 2D NMR spectra (Table 3). NK30424A had a unique glutarimide structure with an unsaturated 12-membered lactone containing cysteine moiety. NK30424B was a stereoisomer of A. The study of stereochemistry and detail of structure determination will be published elsewhere.

We investigated the inhibitory effects of NK30424A and $\mathrm{B}$ against TNF- $\alpha$ production in thioglycolate elicited murine peritoneal macrophages stimulated with LPS, using method as follows. ICR mice ( 7 weeks old, male, Cherles River Japan) were injected (i.p.) with $2 \mathrm{ml}$ of $4.05 \%$ brewers' thioglycolate medium (DIFCO). Three days later, 
Table 1. Physico-chemical properties of NK30424A and B.

\begin{tabular}{|c|c|c|}
\hline & NK30424A & NK30424B \\
\hline Appearance & Whi te powder & White powder \\
\hline $\operatorname{MP}\left({ }^{\circ} \mathrm{C}\right)$ & $129 \sim 131^{\circ} \mathrm{C}(\mathrm{dec})$ & $129 \sim 133^{\circ} \mathrm{C}(\mathrm{dec})$ \\
\hline$[\alpha]_{D}\left(\mathrm{c} \quad 0.5,20^{\circ} \mathrm{C}\right)$ & $+10.8\left(\mathrm{H}_{2} \mathrm{O}\right)$ & $+11.2\left(\mathrm{H}_{2} \mathrm{O}\right)$ \\
\hline FAB-MS $(m / z$, Pos. $)$ & 627. $(\mathrm{M}+\mathrm{H})^{+}$ & $627(\mathrm{M}+\mathrm{H})^{+}$ \\
\hline & 626 & 626 \\
\hline HRFAB-MS $(m / z)$ & & \\
\hline Found: & $627.2982(\mathrm{M}+\mathrm{H})^{+}$ & $627.3030(\mathrm{M}+\mathrm{H})^{+}$ \\
\hline Calcd: & 627.2951 for $\mathrm{C}_{30} \mathrm{H}_{47} \mathrm{~N}_{2} \mathrm{O}_{10} \mathrm{~S}$ & 627.2951 for $\mathrm{C}_{30} \mathrm{H}_{47} \mathrm{~N}_{2} \mathrm{O}_{10} \mathrm{~S}$ \\
\hline Molecular formula & $\mathrm{C}_{30} \mathrm{H}_{46} \mathrm{~N}_{2} 0_{10} \mathrm{~S}$ & $\mathrm{C}_{30} \mathrm{H}_{46} \mathrm{~N}_{2} \mathrm{O}_{10} \mathrm{~S}$ \\
\hline UV $\lambda \max \operatorname{nm}(\log \varepsilon)$ & $206(4.28), 286(2.53)$ & $206(4.28), 283(2.72)$ \\
\hline$I R \vee \max \mathrm{cm}^{-1}(\mathrm{KBr})$ & $\begin{array}{lllll}3430, & 2925, & 1700, & 1630, & 1380, \\
1263, & 1150, & 1105,980\end{array}$ & $3425,2925,1700,1630,1380$, \\
\hline Rf value on TLC & 0.5 & 0.5 \\
\hline & $\left(n-\mathrm{BuOH}-\mathrm{AcOH}-\mathrm{H}_{2} \mathrm{O}, \quad 4: 1: 1\right)$ & $\left(n-\mathrm{BuOH}-\mathrm{AcOH}-\mathrm{H}_{2} \mathrm{O}, \quad 4: 1: 1\right)$ \\
\hline Color reaction & Ninhydrin, Rydon-Smi th, $\mathrm{KMnO}_{4}$ & Ninhydrin, Rydon-Smi th, $\mathrm{KMnO}_{4}$ \\
\hline Soluble: & $\mathrm{H}_{2} \mathrm{O}, \mathrm{MeOH}, \quad \mathrm{DMSO}$ & $\mathrm{H}_{2} \mathrm{O}, \mathrm{MeOH}, \mathrm{DMSO}$ \\
\hline Insoluble: & Et0Ac, $n$-hexane & Et0Ac, $n$-hexane \\
\hline
\end{tabular}

Table 2. ${ }^{13} \mathrm{C}$ NMR spectral data for NK30424A and $\mathrm{B}$.

\begin{tabular}{|c|c|c|}
\hline \multirow[b]{2}{*}{ Position } & \multicolumn{2}{|c|}{${ }^{3} \mathrm{C}$ NMR $\left(125 \mathrm{MHz}, \mathrm{D}_{2} 0\right) \quad \delta \mathrm{ppm}$} \\
\hline & NK30424A & NK30424B \\
\hline 1 & $177.4(\mathrm{~s})$ & $177.4(\mathrm{~s})$ \\
\hline 2 & $37.1(\mathrm{t})$ & $37.0(t)$ \\
\hline 3 & $27.3(d)$ & 27.4 (d) \\
\hline 4 & $38.1(t)$ & $38.1(t)$ \\
\hline 5 & $177.5(\mathrm{~s})$ & $177.5(\mathrm{~s})$ \\
\hline 6 & $41.5(i)$ & $41.5(t)$ \\
\hline 7 & $65.4(\mathrm{~d})$ & $65.3(d)$ \\
\hline 8 & $48.6(t)$ & $48.6(t)$ \\
\hline 9 & $216.2(\mathrm{~s})$ & $216.0 \quad(\mathrm{~s})$ \\
\hline 10 & 46.7 (d) & 46.8 (d) \\
\hline 11 & 126.6 (d) & 127.1 (d) \\
\hline 12 & $135.0(\mathrm{~s})$ & $135.4(\mathrm{~s})$ \\
\hline 13 & 80.3 (d) & 80.9 (d) \\
\hline 14 & 39.0 (d) & $39.1 \quad(d)$ \\
\hline 15 & 73.2 (d) & 73.4 (d) \\
\hline 16 & 83.2 (d) & 82.9 (d) \\
\hline 17 & 128.4 (d) & 131.1 (d) \\
\hline 18 & 137.9 (d) & 135.7 (d) \\
\hline 19 & $29.1(t)$ & $28.7(\mathrm{t})$ \\
\hline 20 & $31.9(t)$ & $34.1 （ t)$ \\
\hline 21 & 41.6 (d) & 40.5 (d) \\
\hline 22 & $39.4(t)$ & $41.9(t)$ \\
\hline 23 & $173.2(\mathrm{~s})$ & $172.9(\mathrm{~s})$ \\
\hline 24 & $16.0 \quad(\mathrm{q})$ & $15.9 \quad(q)$ \\
\hline 25 & 14.5 (q) & $14.4(q)$ \\
\hline 26 & $11.6(\mathrm{q})$ & 11.3 (q) \\
\hline 27 & $56.6 \quad(q)$ & $57.0(q)$ \\
\hline 28 & $31.7(t)$ & $32.1 \quad(1)$ \\
\hline 29 & $54.6(q)$ & 54.7 (d) \\
\hline 30 & $173.4(\mathrm{~s})$ & $173.1(\mathrm{~s})$ \\
\hline
\end{tabular}

peritoneal exudate cells were collected from mice and suspended in RPMI1640 medium. The cells $\left(5 \times 10^{5}\right.$ cells/well) were plated on 48 well microplates and cultured for 3 hours. After non-adherent cells were washed out with new medium, attached cells were used as macrophages. Cells were incubated with LPS $(100 \mathrm{ng} / \mathrm{ml})$ and test compounds for 20 hours. TNF- $\alpha$ bioactivity was measured in the culture supernatant fluids according to the method of actinomycin D treated murine L929 cell (ATCC culture collection) cytotoxicity assay ${ }^{3)}$. The results are summarized in Fig. 2. NK30424A and B showed a concentration dependent inhibition of LPS-induced TNF- $\alpha$ secretion. The effective concentrations $\left(\mathrm{IC}_{50}\right)$ of NK30424A and B were 1 $\mu \mathrm{M}, 0.9 \mu \mathrm{M}$, respectively. In addition, NK30424A and B, at a concentration of $3 \mu \mathrm{M}$, did not show any effects on macrophage survival over 20 hours as demonstrated by MTT assay (data not shown). Therefore, the inhibitory effects of these compounds on the production of TNF- $\alpha$ are not due to cytotoxicity. On the other hand, NK30424A and $B$ inhibited LPS-induced TNF- $\alpha$ promoter activities in J774.1 cells with $\mathrm{IC}_{50}$ of $0.64 \mu \mathrm{M}$ and $0.44 \mu \mathrm{M}$, respectively. These results suggest that effects of NK30424A and B on the production of TNF- $\alpha$ were dependent on its promoter inhibitory action.

It is likely that NK30424A and B suppress NF- $\kappa$ B signaling pathway because it is known that $N F-\kappa B$ is indispensable in LPS-induced TNF- $\alpha$ production ${ }^{1,5)}$. 
Table 3. ${ }^{1} \mathrm{H}$ NMR spectral data for NK30424A and B.

\begin{tabular}{|c|c|c|}
\hline \multirow[b]{2}{*}{ Position } & \multicolumn{2}{|c|}{ H NMR $\left(500 \mathrm{MHz}, \mathrm{D}_{2} 0\right), \quad \delta \mathrm{ppm}(J$ in $\mathrm{Hz})$} \\
\hline & NK30424A & NK30424B \\
\hline 2 & $2.45(1 \mathrm{H}, \mathrm{m})$ & $2.47(1 \mathrm{H}, \mathrm{ml})$ \\
\hline & $2.80(1 \mathrm{H}, \mathrm{m})$ & $2.80(1 \mathrm{H}, \mathrm{m})$ \\
\hline 3 & $2.41(1 \mathrm{H}, \mathrm{m})$ & $2.45(1 \mathrm{H}, \mathrm{m})$ \\
\hline 4 & $2.46(1 \mathrm{H}, \mathrm{m})$ & $2.48(1 \mathrm{H}, \mathrm{m})$ \\
\hline & $2.73(1 \mathrm{H}, \mathrm{m})$ & $2.77(1 \mathrm{H}, \mathrm{m})$ \\
\hline 6 & $1.50(1 \mathrm{H}, \mathrm{m})$ & $1.51(1 \mathrm{H}, \mathrm{m})$ \\
\hline & $1.60(1 \mathrm{H}, \mathrm{m})$ & $1.61(1 \mathrm{H}, \mathrm{m})$ \\
\hline 7 & $4.19(1 \mathrm{H}, \mathrm{m})$ & $4.20(1 \mathrm{H}, \mathrm{ml})$ \\
\hline 8 & $2.72(2 \mathrm{H}, \mathrm{m})$ & $2.75(2 \mathrm{H}, \mathrm{m})$ \\
\hline 10 & $3.63(1 \mathrm{H}, \mathrm{dq}, 9.8,6.4)$ & $3.64(1 \mathrm{H}, \mathrm{dq}, 9.6,6.6)$ \\
\hline 11 & $5.26(1 \mathrm{H}, \mathrm{br} d, 9.6)$ & $5.30(1 \mathrm{H}$, br d, 9.6$)$ \\
\hline 13 & $4.94(1 \mathrm{H}, \mathrm{d}, 2.4)$ & 5.09 (1H, br d, 2.4$)$ \\
\hline 14 & $2.03(1 \mathrm{H}, \mathrm{m})$ & $2.05(1 \mathrm{H}, \mathrm{m})$ \\
\hline 15 & $3.75(1 \mathrm{H}, \mathrm{dd}, 9.4,4.8)$ & $3.75(1 \mathrm{H}, \mathrm{dd}, 9.4,2.4)$ \\
\hline 16 & $3.55(1 \mathrm{H}, \mathrm{dd}, 9.4,7.4)$ & 3.58 ( $1 \mathrm{H}$, br dd, $9.4,6.8)$ \\
\hline 17 & $5.48(1 \mathrm{H}, \mathrm{dd}, 16.0,7.4)$ & $5.49(1 \mathrm{H}, \mathrm{dd}, 16.2,6.8)$ \\
\hline 18 & 5.81 (1H, ddd, $16.0,6.4,6.4)$ & 5.86 (1H, ddd, $16.2,7.4,7.4)$ \\
\hline 19 & $2.15(1 \mathrm{H}, \mathrm{m})$ & $2,21(1 \mathrm{H}, \mathrm{m})$ \\
\hline & $2.43(1 \mathrm{H}, \mathrm{m})$ & $2.27(1 \mathrm{H}, \mathrm{m})$ \\
\hline 20 & $1.87(1 \mathrm{H}, \mathrm{m})$ & $1.58(1 \mathrm{H}, \mathrm{m})$ \\
\hline & $2.11(1 \mathrm{H}, \mathrm{m})$ & $1.87(1 \mathrm{H}, \mathrm{m})$ \\
\hline 21 & $3.34(1 \mathrm{H}, \mathrm{m})$ & $3.20(1 \mathrm{H}, \mathrm{m})$ \\
\hline 22 & $2.67(1 \mathrm{H}, \mathrm{dd}, 17.4,11.8)$ & $2.52(1 \mathrm{H}, \mathrm{dd}, 15.4,10.2)$ \\
\hline & $2.85(1 \mathrm{H}, \mathrm{dd}, 17.4,3.2)$ & $3.00(1 \mathrm{H}, \mathrm{dd}, 15.4,2.8)$ \\
\hline 24 & $1.15(3 \mathrm{H}, \mathrm{d}, 6.6)$ & $1.16(3 \mathrm{H}, \mathrm{d}, 6.6)$ \\
\hline 25 & $1.78(3 \mathrm{H}, \mathrm{d}, 1.0)$ & $1.83(3 \mathrm{H}, \mathrm{d}, 1.2)$ \\
\hline 26 & $0.98(3 \mathrm{H}, \mathrm{d}, 7.2)$ & $1.00(3 \mathrm{H}, \mathrm{d}, 7.4)$ \\
\hline 27 & $3.31(3 \mathrm{H}, \mathrm{s})$ & $3.35(3 \mathrm{H}, \mathrm{s})$ \\
\hline 28 & 3.05 (1H, dd, 14.6, 9.6) & $3.10(1 \mathrm{H}, \mathrm{dd}, 14.2,7.8)$ \\
\hline & $3.21(1 \mathrm{H}, \mathrm{dd}, 14.6,4.4)$ & $3.25(1 \mathrm{H}, \mathrm{dd}, 14.2,4.0)$ \\
\hline 29 & $3.96(1 \mathrm{H}, \mathrm{dd}, 9.6,4.4)$ & $3.95(1 \mathrm{H}, 7.8,4.0)$ \\
\hline
\end{tabular}

Fig. 2. Inhibitory effects of NK30424A and B against TNF- $\alpha$ production in thioglycolate elicited murine peritoneal macrophages stimulated with LPS.

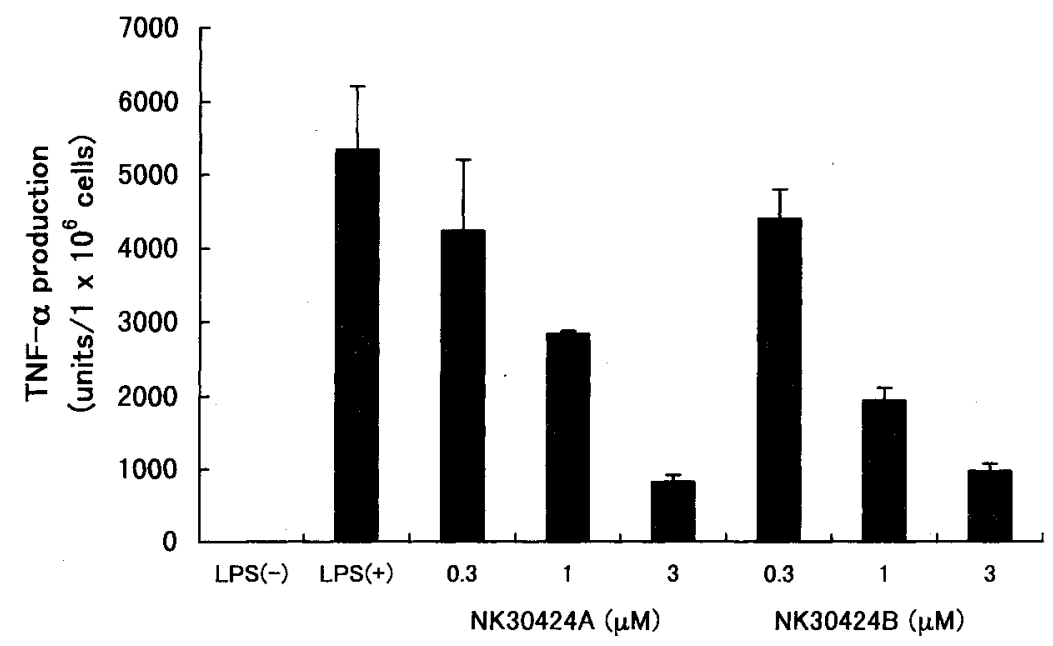

Cells were incubated with LPS $(100 \mathrm{ng} / \mathrm{mi})$ and test compounds for 20 hours. TNF- $\alpha$ bioactivity was measured in the culture supernatant fluids. Data represent mean $\pm S D(n=3)$. 
Although more extensive studies on molecular mechanism of these inhibitors are needed, NK30424A and B can be lead compounds for agents for pathophysiologic diseases that are promoted by constitutive activation of NF- $\kappa \mathrm{B}$ signaling pathway, such as rheumatoid arthritis, multiple sclerosis and cancer.

\section{YOSHIYUKI TAKAYASU KOUICHI TSUCHIYA TAKAYUKI AOYAMA YOSHIKAZU SUKENAGA}

Research and Development Division, Pharmaceuticals Group, Nippon Kayaku Co., Ltd.,

31-12, Shimo 3-chome, Kita-ku, Tokyo 115-8588, Japan

(Received July 30, 2001)

\section{References}

1) Cordie, S. R.; R. Donald, M. A. Read \& J. Hawiger: Lipopolysaccharide induces phosphorylation of MAD3 and activation of $\mathrm{c}-\mathrm{Rel}$ and related $\mathrm{NF}-\kappa \mathrm{B}$ proteins in human monocytic THP-1. J. Biol. Chem. 268: 11803 11810,1988

2) KARIN, M.: How NF- $\kappa$ B is activated: the role of the $I \kappa B$ kinase (IKK) complex. Oncogene 18: 6867 6874, 1999

3) RAYET, B. \& C. GÉlinas: Aberrant rel/nfkb genes and activity in human cancer. Oncogene 18: 6938 6947, 1999

4) Kiener, P. A.; F. MAReK, G. Rodgers, P. F. Lin, G. WARR \& J. DESIDERO: Induction of tumour necrosis factor, IFN$\gamma$ an acute lethality in mice by toxic and non-toxic forms of lipid A. J. Immunol. 141: 870 874, 1988

5) Shakhov, A. N.; M. A. Collart, P. Vassalli, S. A. Nedospasov \& C. V. JongenEel: $\kappa$ B-Type enhancers are involved in lipopolysaccharide-mediated transcriptional activation of the tumour necrosis factor- $\alpha$ gene in primary macrophages. J. Exp. Med. 171: 35 47, 1990 